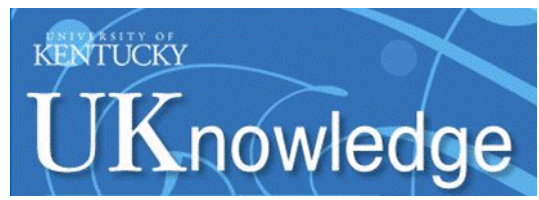

University of Kentucky

UKnowledge

\title{
Investment in Human Capital and Labor Mobility: Evidence from a Shock to Property Rights
}

\author{
Christopher P. Clifford \\ University of Kentucky, chris.clifford@uky.edu \\ William C. Gerken \\ University of Kentucky, will.gerken@uky.edu
}

Follow this and additional works at: https://uknowledge.uky.edu/isfe_papers

Part of the Economics Commons, and the Human Resources Management Commons

Right click to open a feedback form in a new tab to let us know how this document benefits you.

\section{Repository Citation}

Clifford, Christopher P. and Gerken, William C., "Investment in Human Capital and Labor Mobility: Evidence from a Shock to Property Rights" (2019). Institute for the Study of Free Enterprise Working Papers. 14. https://uknowledge.uky.edu/isfe_papers/14

This Research Paper is brought to you for free and open access by the Institute for the Study of Free Enterprise at UKnowledge. It has been accepted for inclusion in Institute for the Study of Free Enterprise Working Papers by an authorized administrator of UKnowledge. For more information, please contact UKnowledge@lsv.uky.edu. 


\title{
Investment in Human Capital and Labor Mobility: Evidence from a Shock to Property Rights
}

\section{Christopher P. Clifford William C. Gerken}

\author{
January 2019
}

Institute for the Study of Free Enterprise Working Paper 16

\author{
University of Kentucky \\ 244 Gatton College of Business and Economics \\ Lexington, KY 40506-0034 \\ http://isfe.uky.edu/
}

\section{Gatton College of




\title{
Investment in Human Capital and Labor Mobility: Evidence from a Shock to Property Rights
}

\author{
Christopher P. Clifford and William C. Gerken \\ Department of Finance and Quantitative Methods, University of Kentucky, Lexington, KY \\ 40506
}

We show that the assignment of property rights to client relationships affects employee behavior in the industry for financial advice. Our identification comes from staggered firm-level entry into the Protocol for Broker Recruiting. The protocol effectively transfers the ownership of the client relationship from the firm to the employee. We document that entering into the protocol increases employee labor mobility among member firms. Further, we find that upon protocol inclusion, employees are less likely to generate customer complaints and more likely to invest in their own general human capital, but less likely to invest in firm-specific human capital. We use detailed employee-employer matched data for the universe of financial advisors to show that these effects hold within the same job spell and across advisors within the same county at the same time. Our results suggest that limiting labor mobility may limit employee incentives to invest in human capital.

Keywords: property rights, labor mobility, financial advisors, non-solicitation agreements, Protocol for Broker Recruiting

JEL Codes: G24, J44, J60, K31, L22

We thank seminar and conference participants at Georgia Tech, 2017 MarketSummit (Miami), the Beyster Institute (Rutgers University), the SFS Cavalcade (Yale University), the Professional Asset Management Conference (Erasmus University), the Mitsui Symposium on Labor and Finance (University of Michigan), and the Western Finance Association (San Diego). We thank John Bizjack (discussant), Sudheer Chava, Alan Kwan, Phil Mellizo (discussant), Paige Ouimet, Juan Pedro Gomez (discussant), Jess Cornaggia (discussant), and Brian Melzer (discussant) for valuable comments. We acknowledge the support of the John H. Schnatter Institute for the Study of Free Enterprise. Finally, we are grateful to Jeremy Wallace of Wallace Hart Capital Management for helpful discussions about the protocol.

E-mail addresses: chris.clifford@uky.edu (Christopher P. Clifford) and will.gerken@uky.edu (William C. Gerken) 


\section{Introduction}

Why would a firm allow an employee to take valuable assets out of the building upon their departure? In August 2004, three large financial advisory firms-Smith Barney, Merrill Lynch, and UBS - entered into a private agreement, the Protocol for Broker Recruiting (protocol), that allowed departing financial advisors to solicit their clients when moving to other protocol member firms without fear of legal recourse. ${ }^{1}$ Over the next decade, over 1,500 firms joined this pact. In doing so, they willingly transferred their property rights in a key asset to their employees by effectively waiving preexisting non-solicitation clauses.

While patents and trademarks help to protect intellectual property rights for the firm, other forms of tacit human capital, such as relationships with clients, do not permit codification or armslength exchange. Though individual advisors often view the clients they work with as "their" clients, the legal reality is that they are clients of the financial advisory firm. This arrangement presents a distinction without a difference until an advisor wants to leave their employer. Given the inalienable nature of advisor-client relationships, firms may choose to protect this type of human capital through contractual mechanisms such as non-compete and non-solicitation agreements. While such agreements are generally found to deter employee exit, what effect they have on employee effort is less understood. If advisors are restricted from taking their clients when they leave a firm, then the client relationship is firm-specific human capital, and investment in the relationship may be inefficiently low due to a holdup problem (Grossman and Hart, 1986). In our

\footnotetext{
${ }^{1}$ Following the convention in the academic literature (e.g., Egan, Matvos, and Seru 2017 and Dimmock, Gerken, and Graham 2017), we will use the term "financial advisor" to refer to investment professionals registered with FINRA. The Securities and Exchange Act of 1934 defines "broker" broadly as "any person engaged in the business of effecting transactions in securities for the account of others." In the United States, all brokers must register with FINRA.
} 
paper, we study a shock that reassigns the ownership of this relationship to better understand the role of property rights and human capital investment.

Studying these issues empirically is challenging. Typically, whether a particular investment in human capital is general or firm-specific is an immutable characteristic. In the financial advisory industry, the advent of the protocol changed investments in client relationships from firm-specific to general human capital investments for some but not all advisors. Thus, advisors competing in the same geographic area at the same time have different specificity to their client-relationship investments. Moreover, we even observe this change in property rights within the same employee-employer relationship (job spell), allowing us to dismiss alternative explanations such as advisors selecting into protocol firms following their inclusion.

To study this industry, we obtain data from BrokerCheck and the Investment Adviser Public Disclosure (IAPD) database. These two databases allow us to track the career paths of 1.3 million unique advisors across more than 50,000 firms. The data give precise dates and branch locations on when individuals are employed with member firms, achieve professional advancement, receive customer disputes and other complaints of misconduct, and start new firms. Moreover, a series of standardized industry licenses allows us to track employee investments in human capital in a systematic manner. The data allow us to not only control for observable characteristics, but to use high dimensional fixed effects to control for unobservable heterogeneity across time, geography, firms, and individuals (and their interactions).Thus, we argue that the introduction of the protocol makes an ideal context in which to study the effects of the assignment of property rights on the development of human capital.

Consider the example of two advisors working in the Raleigh, North Carolina, area: one works for UBS and one works for Edward Jones. Their offices are less than 400 feet away from 
each other and face each other, overlooking the 3700 block of Glenwood Ave. Each is positioned less than three miles from the prestigious Carolina Country Club, and they likely compete for the same clients. In 2004, executives in UBS's corporate offices in New York decided to join the protocol, while executives in Edward Jones's St. Louis office did not (and still had not by the end of our sample period). We test how, at that moment, the exogenous (to the advisor) change in property rights affects the UBS advisor's behavior relative to that of the Edward Jones advisor. Does the UBS advisor treat the client relationship differently now that he owns the asset? Does he seek additional licensing or career certification or leave to join a competing firm? We can control for observable characteristics (e.g., tenure in the industry) that may affect these choices, but given that we know the branch location of these two advisors, we can also use geographic fixed effects to control for unobservable heterogeneity in the Glenwood area of Raleigh that may influence these choices. Further, because protocol membership changes over time, ${ }^{2}$ and thus the shock to property rights is staggered, we can compare workers at different firms at the same time, the same individual at different points in time, and even individuals at the same firm at the same time across geographical regions.

We first document that participation in the protocol affects labor mobility among financial advisors. Firms that join the protocol see turnover increase in their workforce, and the effect is more pronounced among more experienced advisors. We also see that firms are more likely to poach and be poached by other protocol firms, consistent with membership lowering the barriers to transfer between member firms. On net, protocol firms experience a growth in the number of employees, and these new hires tend to be more experienced. However, after joining the protocol,

\footnotetext{
${ }^{2}$ Morgan Stanley, which also has a branch in the same office complex on Glenwood Avenue, joined the protocol in 2006.
} 
firms see an increase in the number of their existing advisors who decide to leave and start their own firms.

We next examine the behavior of the individual advisor. After an advisor's firm joins the protocol, granting the advisor property rights in the client relationship, we observe that the advisor takes better care of the asset, as evidenced by lower rates of customer disputes. Further, we find that advisors invest in their own human capital by sitting for additional industry licenses that allow them to shift their business from a short-term, commission-based approach to a long-term, feebased approach. We observe the actual exam scores for each advisor and find that employees perform better on these exams when their employer is in the protocol, suggesting that inclusion not only affects the extensive margin to invest in human capital, but the intensive margin as well. Finally, we find that advisors are less likely to obtain the Series 24 principal's license following protocol inclusion. This license grants an employee the ability to act in a supervisory role within the firm (approving new accounts, approving transactions, supervising branch employees, etc.), a role that may be difficult to transfer across different firms in the industry. Thus, as labor mobility improves, advisors appear to shift human capital investment to forms that are more easily transferable within the industry.

In each of these tests, we control for confounding variation by examining within-advisor, within-firm changes in these rates. We also address other time-varying explanations by controlling for the specific licenses an advisor gains over time as well as controlling for county-year fixed effects. These strategies allow us to rule out alternative explanations based on changes in business lines, regulatory phenomena, or economic conditions. In some specification, we focus on withinjob-spell variation, which also rules out concerns about employee-employer matching. 
We also examine the firm-level consequences associated with joining the protocol. We find within-firm evidence that revenues, assets under management, and number of accounts increase after joining the protocol; these increases remain even after accounting for the increase in number of employees. Given these results, a natural question to ask is, why do all firms not join? Firms may correctly fear that they will lose more human capital through employee exit than they will gain from attracting new advisors and increased production from existing advisors.

Our paper is related to a growing literature on labor restrictions and investment. Establishing a causal relationship between labor mobility and the actions of employees and firms is challenging. A series of papers utilizes geographic differences in enforceability (and, in some cases, time-series variation in enforceability due to judicial decisions) of post-employment covenants not to compete as a source of variation in mobility. Gilson (1999) examines differences between the enforceability of non-compete agreements in Silicon Valley and Massachusetts' Route 128 (Boston's technology corridor). He argues that the relative rise of Silicon Valley over Route 128 is partially explained by California's unwillingness to enforce non-compete agreements, leading to increased labor mobility in Silicon Valley and increased knowledge spillovers between its firms. Garmaise (2011) finds that the use of non-compete contracts reduces labor mobility and binds human capital to the firm, but that these contracts affect the managers' incentives to invest in their own human capital, thereby reducing the value of the human capital stock. Jeffers (2017) also finds that the enforceability of non-compete contracts reduces labor mobility, but that enforceability is associated with an increase in capital investment by the firm, suggesting that reducing labor mobility may affect firms' capital stocks if replacing human capital is costly. Lavetti, Simon, and White (2017) show that by deterring the poaching of patients, non-compete agreements at physician practices increase the rate of return to job tenure. They argue that the 
evidence is consistent with non-compete agreements enabling practices to allocate patients to new physicians through intra-firm patient referrals, reducing a form of investment holdup. Barnett and Sichelman (2016) note that the enforceability of non-compete agreements is only one of many tools that firms may use to restrict labor mobility. Even in California, a state that bans the enforcement of non-competes, firms may use trade-secret litigation and deferred compensation to reduce mobility.

In contrast with non-compete agreements that prohibit a former employee from competing against a former employer for a specified amount of time, the non-solicitation agreements we examine are more narrowly aimed at preventing an employee from soliciting his former employer's clients. Therefore, the protocol allows us to isolate the effect of the value of the client relationship (which is subject to the non-solicitation agreement) from the employee's ability to work in the industry.

Our paper also contributes to the emerging literature on the financial advisory industry. Existing studies generally document that advisors do little to aid clients and instead harm performance by steering them toward high-fee products or the advisor's own personal biases (see, e.g., Bergstresser, Chalmers, and Tufano, 2009; Chalmers and Reuter, 2015; Hackethal, Haliassos, and Jappelli, 2012; Hoechle et al., 2017; Mullainathan, Noeth, and Schoar, 2012; Foerster et al., 2017). Egan, Matvos, and Seru (2017) show that a significant percentage of advisors have disputes with their clients and suggest that certain firms "specialize" in misconduct and cater to unsophisticated consumers. Several papers examine other factors associated with dispute rates. Dimmock, Gerken, and Graham (2017) show that advisors learn from their peers and that misconduct is contagious among co-workers. Charoenwong, Kwan, and Umar (2017) show that advisors' behavior responds to regulator identity. In our paper, we document that advisors' 
treatment of clients is related to the internal incentives created by the assignment of property rights to the client relationship.

We also contribute to the literature on property rights, ownership, and boundaries of the firm. Assignment of ownership can encourage asset-specific human capital investments by reducing the threat of holdup (Williamson, 1979; Grossman and Hart, 1986; Hart and Moore, 1990). Simester and Wernerfelt (2005) use a data set describing ownership of productive assets in the carpentry trade to evaluate several factors influencing the allocation of asset ownership between an employer and its employees. They find that employees are generally more careful with their own tools (the productive asset) than with the tools owned by the firm. Massa, Reuter, and Zitzewitz (2010) show that mutual fund families weigh the benefits of naming managers (which, they argue, gives the manager "ownership" of the fund's record) against the cost associated with the manager's increased future bargaining power (in this context, moving to a hedge fund). In the context of the trucking industry, Baker and Hubbard (2004) exploit the introduction of onboard computers as a shock to non-contractable driver care (by making care observable) to examine its effect on ownership. In our paper, we observe a shock to property rights and examine how employees change their investments in general and firm-specific human capital in response.

The remainder of the paper is organized as follows. Section 2 describes the financial advisory industry and the Protocol for Broker Recruiting. Section 3 reviews the data and variables. In Section 4, we show how labor mobility changes around the protocol. In Section 5, we examine how individual advisors react to the protocol. Section 6 documents firm-level outcomes around the protocol. Section 7 concludes.

\section{Empirical Setting}


Over 643,000 individuals were registered with the Financial Industry Regulatory Authority (FINRA) in 2016. They generated more than $\$ 98$ billion in revenues and managed over $\$ 3.4$ trillion in assets. ${ }^{3}$ The industry affects the well-being of many households: Hung et al. (2008) report that 73 percent of individual investors use an advisor for investment decisions (outside of employersponsored retirement plans).

Gennaioli, Shleifer, and Vishny (2015) argue that financial advice is a trust-based service, similar to medicine. Patients trust their doctors and do not want to go to a random doctor, even if equally qualified; clients of financial advisors are similarly attached. Although the issues we discuss apply more generally to all firms that provide trust-relationship services, we use the financial advisory industry as our empirical setting. A key feature is that the advisory relationships with clients cannot be completely codified or replicated such that the client relationship is inalienable from the advisor.

The role of the advisor-client relationship is central to the revenue-generating process of the advisory firm. Firms face the choice of hiring advisors that are new to the industry and investing in them as they slowly build their books of business or hiring away from competitors experienced advisors with established books. In an effort to quickly grow assets under management (and hence revenues), a recruiting firm's hope is that a recruited advisor's clients will relocate to the new firm. A 2013 report from Cerulli Associates finds that advisors indicate success in transferring over 90\% (71\%) of their targeted assets (total assets) when changing firms.

In response to the recruitment of their employees, incumbent firms often seek temporary restraining orders and sue departing advisors for breach of employment contract in the hope of preventing solicitation of past clients. Though often laid out in employment agreements, ownership

\footnotetext{
${ }^{3}$ The numbers are based on X-17 FOCUS filings in 2013.
} 
claims on the advisor-client relationships of departing advisors are subject to the enforceability of the employment agreement in the court system. Thus, an important feature of this industry is the widespread use of non-solicitation agreements. In contrast with non-compete agreements that prohibit a former employee from competing against a former employer for a specified amount of time, non-solicitation agreements are more narrowly aimed at preventing an employee from soliciting his former employer's clients. An example of a non-solicitation clause is given below:

I agree that for a period of one year following my termination, I will not solicit by mail, by phone, by personal meeting, or by any other means, either directly or indirectly, any Account whom I served or whose name became known to me during my employment at [firm] in any office and in any capacity.... The only exception will be my family and relatives.

Courts have generally ruled more favorably on enforcing non-solicitation agreements compared to non-compete agreements, as non-solicitation agreements impose fewer limitations on an employee's right to work. While courts have found that non-compete agreements substantially restrict an employee's ability to seek other employment, non-solicitation agreements are usually viewed by courts as imposing reasonable conditions since they allow the employee to continue working in his area of expertise.

\subsection{The Protocol for Broker Recruiting}

The Gramm-Leach-Bliley (GLB) Act, also known as the Financial Services Modernization Act of 1999, prohibits financial institutions from sharing a client's private information with other financial firms without the client's consent. After the act's passage, poaching firms could no longer prepare account-transfer papers that included data on account and Social Security numbers in 
advance of advisors' transitions. During the transition period, departing advisors were often faced with temporary restraining orders by their former firms, while both firms fought over whether the clients were free to transition to the new firm. Such disputes, in which client relationships were publicly treated as property, did not project the image of client focus that the financial advisory firms tried to foster.

In response to rising litigation, to compete freely to recruit new advisors, and to enhance incentives for existing advisors, on August 19, 2004, Citigroup Global Markets (Smith Barney), UBS Financial Services, and Merrill Lynch, Pierce, Fenner \& Smith entered into the Protocol for Broker Recruiting to allow advisors to transfer from one protocol firm to another without fear of legal recourse. The protocol allows departing advisors to take five pieces of client data: names, addresses, phone numbers, e-mail addresses, and account titles. The full text of the protocol is provided in the Appendix. The protocol has been subjected to legal challenges, and courts have consistently held member firms to the terms of the protocol; however, a number of claims are excepted from the protocol, including soliciting customers prior to resignation, retaining customer records or information beyond what is permitted under the protocol, soliciting fellow employees to resign from the old firm, breaching a partnership agreement, and collecting sums due under promissory notes or training agreements. Importantly, protocol advisors moving to non-protocol firms do not receive similar treatment. ${ }^{4}$

\subsection{Advisor Transition under the Protocol}

The client relationship is legally with the firm, not with the individual advisor. Therefore, under the protocol, solicitation of an advisor's clients by the new firm, before the advisor has left his

\footnotetext{
${ }^{4}$ For example, see Fidelity Brokerage Services LLC v. Brian Wilder \& Morgan Stanley Smith Barney LLC, FINRA Arbitration Number 11-03937.
} 
current firm, is a breach of the employment agreement with the advisor's current firm and can lead to immediate termination. Typically, the advisor resigns in writing to the local branch manager and delivers the resignation in person. The key elements of the resignation letter include the notice of the decision to resign, the effective date (usually immediate), and, per the requirements of the protocol, a copy of the exact client information and documentation that the advisor is taking to the new firm (names, addresses, phone numbers, e-mail addresses, and account titles). Additionally, the advisor must include a list of all the account numbers associated with the advisor's client accounts (which the advisor is not allowed to retain). While the protocol effectively overrides the existing employment agreement's non-solicitation terms, the rest of the employment agreement still applies and must still be complied with. For example, upon exit, the advisor may be liable for retention deals such as forgivable loans, which are common in the industry. Further, the protocol generally only applies for clients that advisors generated themselves.

Transitioning advisors may not solicit their former clients until formally registering with their new firms. Industry custom is for transitioning advisors to move on a Friday (preferably before a three-day weekend) so that they have the entire weekend to attract their former clients before their prior firms can react. In Figure 1, we document that advisors moving between firms are more likely to transition on a Friday, and in unreported tests, we find evidence that the effect is even stronger on Fridays before three-day weekends.

Though individual advisors and even small teams are allowed to depart under the protocol, when a recruiting firm takes a large number of advisors and staff at once, it opens itself to claims of "raiding". While claims of raiding are contentious, raiding is not protected under the protocol, as precise definitions are not provided. 


\subsection{Identification}

Our empirical objective is to identify the effect of property rights and increased labor mobility on financial advisors' behavior and human capital investment. The central issue regarding causality is that financial advisory firms may choose to enter the protocol; thus, financial advisors are not randomly allocated into this treatment. As a result, a correlation between an individual's protocol status and their choice to invest in human capital could arise for a variety of reasons. For example, inclusion in the protocol could enhance the advisor's labor mobility and encourage the advisor to invest more in his own human capital. Alternatively, higher-quality advisors might continuously invest in their human capital, and if firms with large proportions of high-quality advisors join the protocol, we could observe a correlation between protocol and human capital investment that does not imply a causal relationship between the two.

A key advantage of our setting is that we observe the time-varying individual actions of employees who are geographically dispersed. Moreover, different firms (and thus their employees) enter the protocol at varied times during our sample period. We can interpret our estimates as causal only if protocol membership is related to unobserved factors that affect advisor behavior. We therefore rely on the richness of our data set to include a bevy of fixed effects along several key dimensions to condition out potential confounding factors.

In our main results that examine the human capital investment decisions of advisors, we include county-year fixed effects. By conditioning out time effects, we remove potentially confounding variation due to time-varying, industry-wide changes such as those due to technological changes like the growth of the internet or economic events like the financial crisis. Further, by employing year and county interaction effects, we also control for time-varying changes in the regulatory environment (subsuming state-level variation as well). These effects will 
also control for differences in local labor market and economic conditions across time. Our setting allows us to compare individuals (some of whom work for a protocol member and some of whom do not) that work in the same location (county) at the same time and therefore face similar economic incentives to invest in human capital.

The nature of our data also allows us to track advisors across time and firms. This permits us to include firm effects that remove any time-invariant characteristics of the firm that employs the advisor, such as differences in business models across firms. The individual advisor fixed effect removes all time-invariant characteristics of the advisor, including their overall propensity to invest in human capital or ability. It also controls for the effects of characteristics that are essentially fixed at the time the individual begins working as an advisor, such as educational background and gender.

We perform a test of the difference in average customer dispute growth rates across the treatment and control groups during the pretreatment era. We find that these differences are both statistically and economically insignificant (coefficient of 0.001 ; $t$-stat of 0.40 ), suggesting that after including our host of controls, advisors that enter the protocol had parallel trends to those that did not in the pretreatment period. As an additional check, in Figure 3, we plot a times series of the coefficient estimate on interaction Protocol with years to treatment (firm entrance into the protocol). Prior to protocol entrance, the estimated differences of future protocol advisors' misconduct rates are statistically (and economically) indistinguishable from the control group. After protocol entrance, the treated advisors show a significant drop in misconduct rates.

In several specifications, we include advisor-firm fixed effects. Our identification comes from the time-series variation in individuals' human capital investment and from their protocol status while they are employed by a specific firm. There are 198,616 job spells (advisor-firm pairs) 
in which Protocol varies during the employment spell. Including these spell fixed effects conditions out any within-advisor variation in human capital due to match effects. Importantly, in these tests, the effect of the protocol relies solely on those advisors that join a firm before the firm enters the protocol and remain with the firm after the firm enters the agreement. Thus, we remove any effects of sorting of employees based on contemporaneous protocol status. These effects subsume the individual advisor and firm fixed effects. ${ }^{5}$

Finally, in addition to careful control of advisor and advisor-firm matching, in certain specifications, we also attempt to exploit geographic differences in the enforcement of non-solicit agreements as a source of intensive-margin variation in property rights. During our sample period, courts in California, Montana, North Dakota, and Oklahoma tended to take a dimmer view of nonsolicit agreements. In these states, we expect any changes to advisor incentives to invest in human capital to be more muted when compared to other states. Unlike many other professions, geographic mobility may be limited for financial advisors, as clients often require face-to-face meetings. An example of this preference is seen on FINRA's BrokerCheck website that allows investors to search for local financial advisors within a 5-, 15-, or 25-mile radius.

\section{Data and Summary Stats}

\subsection{The Protocol for Broker Recruiting}

We obtain data on signatories to the protocol from the website maintained by Carlile, Patchen, \& Murphy LLP. ${ }^{6}$ The website lists the firm's legal name, contact person information, the date the firm joined, and the date the firm withdrew (if any). Firms are listed if, at any point in time, they

\footnotetext{
${ }^{5}$ When using job-spell effects, all time-invariant covariates are not identified, but the estimates of the time-varying covariates (such as protocol membership) are consistent. If there is just one observation per spell, then the singleton observation must be dropped in order to calculate standard errors correctly (Correia 2015).

${ }^{6}$ The Broker Protocol, http://www.thebrokerprotocol.com/.
} 
were a signatory. We are able to match the legal names from FINRA Form BD and Securities and Exchange Commission (SEC) Form ADV filings to obtain Central Registration Depository (CRD) numbers for signatories. To match ambiguous cases, we use the individual registrations of contact persons or firm phone numbers and e-mail domains. In Table 1, we report the names and dates of the large firms that joined the protocol during our sample period. In Figure 2, we show the growth of membership over time. When the founding members (UBS, Merrill Lynch, and Smith Barney) joined in 2004, approximately $10 \%$ of the advisors in the industry became subject to the protocol. ${ }^{7}$ Other large firms, Wachovia and Raymond James, followed in 2006, and protocol coverage grew steadily thereafter, reaching over $40 \%$ by the end of our sample. Several large and notable firms, such as Edward Jones, Commonwealth Financial Network, and Goldman Sachs, have never joined. While withdrawal is permitted and easy (requiring only a 10-day notice), fewer than 100 (predominantly small) firms withdrew from the protocol during the period we studied.

\subsection{Financial Advisors}

The data on financial advisors come from FINRA Form U4, which provides detailed information on advisors' characteristics, employment histories, and history of misconduct. In the United States, all registered representatives (the legal term for what we call "financial advisors") must be registered with FINRA by their employer using Form U4. This form must be updated following any material change in the advisor's information (including change in employment or disclosure of misconduct). FINRA and state regulators jointly operate the CRD, which serves as a repository for Form U4 and related regulatory filings. The CRD assigns each advisor and firm a unique

\footnotetext{
${ }^{7}$ Stephens, Inc., a smaller firm based in Little Rock, Arkansas, also joined later in 2004.
} 
identification number that remains constant over time, allowing us to carefully track employment movements. FINRA shares much of this information with the public via its BrokerCheck website.

We built a data set of financial advisors from disclosures available through BrokerCheck. We used these disclosures to create an annual panel data set that provides information about each individual advisor over the period 1999-2016, including the advisor's employer, the branch location of the advisor's employer, and information about customer complaints, regulatory actions, and other types of misconduct.

In total, the data set contains 1.3 million financial advisors and over 50,000 firms. We also obtained more detailed data from state regulators via a series of Freedom of Information Act requests for a subset of advisors. We summarize key attributes of the data in Panel A of Table 2 for all advisors as of the final year of our sample. We report sample averages separately for advisors employed by protocol and non-protocol firms and find our sample is generally similar to that of Egan, Matvos, and Seru (2017). Advisors employed by protocol firms have more experience, more professional licensing, and are more likely to have an incident of misconduct over their (longer) careers.

\subsection{Financial Advisory Firms}

We obtained firm-level data through SEC Rule 17a-5, which requires that FINRA member firms file an annual audited report. We obtained our sample of 62,045 firm-year observations from 2001 to 2014 through AuditAnalytics. The Financial and Operational Combined Uniform Single (FOCUS) report provides basic financial and operational information such as revenues, assets, and liabilities. We also collected data on firms from Form ADV, which investment advisory firms file with the SEC. We summarize attributes of these data in Panel B of Table 2 for all firms as of the 
final year of our sample. At the end of our sample, protocol firms are much larger than nonprotocol firms in terms of number of employees, revenues, assets, and number of client accounts. Protocol firms are also broader in the number of product lines that they provide and in the number of states in which they are registered. While protocol firms are larger on average, the majority of large firms (> 1,000 employees) in the sample are not protocol members.

\section{The Protocol and Hiring Practices}

In this section, we examine how labor mobility changes around inclusion in the protocol.

In Table 3, we document the effect of the protocol by observing within-firm and within-year hiring practices around a firm's decision to enter the protocol using the follow model:

$$
Y_{\{f, t\}}=\alpha+\beta_{\{1\}\{\text { Protocol }\}_{\{f, t-1\}}}+\gamma\{X\}_{\{f, t-1\}}+\delta_{t}+\delta_{f}+\epsilon_{\{f, t\}}
$$

where $Y$ includes poaching (hiring away an employee from a competitor), turnover (losing an employee to competitor), poaching/turnover levels from/to protocol and non-protocol firms, and turnover that results in the departing employee starting their own firm. Given that protocol inclusion is most likely to affect the hiring of experienced advisors, in all models, we focus on advisors with more than a year of industry experience. ${ }^{8} X$ includes the log number of employees for the firm and the log of the average industry experience for the firm's employees, while $f$ indicates a financial advisory firm and $t$ indicates year. The unit of observation is a firm-year. We cluster standard errors at the firm level and year level.

We begin by noting that firms with more employees unconditionally have a greater change in employee headcount. These firms hire new employees more frequently, poach existing employees away from competitors, and lose their own employees to competitors at a higher rate.

\footnotetext{
${ }^{8}$ In unreported results, we find no significant differences in hiring rookie employees around protocol inclusion.
} 
We find that the average experience of the firm's employees plays a smaller role. Notably, as firms' workforces age, firms are more likely to have employees leave to start their own firms.

Turning to the role of joining the protocol, we find that protocol inclusion is related to the hiring and departure of experienced advisors. We see in Table 3 that after joining the protocol, firms are more likely to hire away advisors from competitors (Column 1) and lose advisors to competitors (Column 4). Given that our data allow us to track what firm the advisor came from and left for, in addition to those firms' own inclusion in the protocol, we can separately measure the effects for how much of the employee turnover occurs from protocol and non-protocol firms.

We find that after joining the protocol, firms poach 16.5 more advisors from protocol firms (Column 2) and reduce their poaching from non-protocol firms by nearly eight employees per year (Column 3). To put these figures in economic context, the average firm in our sample poaches 13.2 employees and loses 10.4 employees a year. ${ }^{9}$ We find similar results for firms losing existing employees. After joining the protocol, firms lose 9.5 employees a year to protocol firms (Column 5) and reduce the number of employees lost to non-protocol firms by 11 employees per year.

Articles in the popular press speak to the unintended consequences of firms joining the protocol. ${ }^{10}$ Specifically, valuable advisors may use the cover of the protocol to leave and start their own firms. Departing employees can do this by creating a shell company that registers for the protocol. These employees then depart their existing firms and join the shell company. Given that both firms are enrolled in the protocol, departing employees that follow the rules of the protocol are able to solicit their clients to join them at the new firm. In Column 7, we examine this form of entrepreneurship. We combine the employment history data from the IAPD with the ownership

\footnotetext{
${ }^{9}$ We note that change in headcount from Columns 2 and 3 does not equal the change in headcount from Column 1 due to the fixed effects.

${ }^{10}$ Fisher Phillips, "RIAs Are Increasingly Reaping the Benefits of the Protocol for Broker Recruiting," n.d., https://www.lexology.com/library/detail.aspx?g=6dc53276-1520-4869-8d71-424e77be8573.
} 
data in Form ADV to examine whether protocol inclusion is related to employees departing to start their own firms. We find that firms in the protocol experience an average loss of two employees that start their own firms relative to average entrepreneurship rates for a given year. We discuss what harm, if any, these losses cause for employers in Section 6.

While firm-level tests such as these should be interpreted carefully given that the choice to join the protocol is endogenous to the firm, they suggest that protocol inclusion is related to changes in firms' employment practices. If human capital may be deployed more efficiently at some firms than others, it is possible for a firm to gain by voluntarily entering into an agreement that allows its employees to leave the firm more easily while at the same time reducing the costs of poaching away employees from other firms. We find that following protocol inclusion, firms experience an increased turnover in employees. Advisors are poached from and away to other protocol firms at increasing rates relative to general employee turnover in a given year.

In the following section, we turn to the effect of the protocol on employees themselves. We argue that protocol inclusion is a shock to property rights from the perspective of an individual advisor. The three founding members of the protocol (UBS, Merrill Lynch, and Smith Barney), for example, each employed an average of over 18,000 advisors in any given year during our sample period. Thus, we assume it is unlikely that any given advisor had a meaningful effect on the firm's decision to join.

\section{Advisor-Level Results}

In our setting, inclusion in the protocol alters the ownership rights of client relationships by shifting the nature of the human capital from more firm-specific to more general. While this change increases the advisor's value in the external labor market, what effect it has on the behavior of the 
advisor and the incumbent firm is less clear. On the one hand, firms may join the protocol out of hubris, believing they will be net winners in the labor market for talented advisors. ${ }^{11}$ All firms cannot be net winners, however, and for some firms, inclusion in the protocol may expedite advisors leaving for greener pastures. In this case, in the absence of other benefits, incumbent firms could be made worse off as talented human capital leaves for their competitors or to start their own firms. Interestingly, few firms choose to leave the protocol even if they are net losers of advisors to other protocol firms. In the prior section, we documented one potential benefit-protocol firms are more attractive to advisors than nonprotocol firms - so there may be a net inflow of talented advisors to these firms.

In this section, we examine another channel by which protocol membership can benefit firms. Advisors realize that additional human capital investments in growing and maintaining their book of business are transferable in protocol firms should they decide to exit, and this could increase their effort. In this case, incumbent firms could be made better off if, in addition to poaching away advisors from competitor firms, they are able to earn additional rents from existing advisors that increase human capital production, even if some fraction of these advisors eventually depart. We study advisor behavior by examining how protocol inclusion affects their relationships with their clients through examining customer disputes and investment in human capital.

\subsection{Client Relationships}

While clients are legally the property of the firm, the individual advisor is the de facto face of the relationship. The advisor maintains the relationship beyond the provision of the financial advice

\footnotetext{
11 "Each firm is arrogant enough to think they are going to be the winner, so they agreed [to join the protocol]," said securities lawyer Dennis Concilla of Carlile Patchen \& Murphy LLP, the law firm that maintains the protocol. Quoted in Megan Leonhardt, “Who Owns Your Clients?” WealthManagement.com, October 24, 2013.
} 
through face-to-face, telephone, and electronic communication. Georgarakos and Inderst (2014) provide evidence that the household's usage of advice is affected both by its own perception of its financial capability and by the trust it puts in professional advice. Gennaioli, Shleifer, and Vishny (2015) argue that a key function of advisors is to convince households to trust the financial system enough to participate in the market. Thus, the trust between advisor and client is important tacit and inalienable human capital.

Inclusion in the protocol converts a client relationship that was firm-specific human capital into general human capital. If financial advisors are allowed to keep their clients when they leave a firm, then advisors have a greater incentive to take care of this relationship asset under the protocol.

Egan, Matvos, and Seru (2017) document labor-market consequences for advisors following incidents of misconduct and find evidence that firms "match on misconduct," meaning that firms with a history of misconduct are more likely to hire advisors with a history of misconduct. They find that reprimanded advisors take longer to find a new position, losing income during the period they are unemployed and incurring the cost to find a new job. Moreover, after losing a job following misconduct, advisors typically end up at substantially smaller, lower-paying firms. Thus, as engaging in misconduct is costly in the labor market, we expect that, all else equal, an advisor has a greater incentive to avoid engaging in misconduct in response to an increase in labor mobility such as that provided by the protocol. We therefore estimate a specification of the form:

$$
\{\text { Misconduct }\}_{\{i, t\}}=\beta_{\{1\}\{\text { Protocol }\}_{\{i, t-1\}}}+\gamma\{X\}_{\{i, t-1\}}+\delta_{i}+\delta_{F}+\delta_{\{c, t\}}+\epsilon_{\{i, t\}}
$$


where $i$ indicates a financial advisor, $F$ indicates a financial advisory firm, and $\{c, t\}$ indicates county-year pair. $\{X\}_{\{i, t-1\}}$ contains time-varying advisor characteristics such as experiences and licenses earned during an advisor's career.

The firm fixed effect removes the time-invariant characteristics of the firm that employs the advisor, which is especially important in this setting as Egan, Matvos, and Seru (2017) suggest that some firms "specialize" in misconduct. Controlling for time-varying licensing ensures that any relationship we observe is not due to a confounding shift in business model during entry into the protocol; e.g., we document in the following subsection that protocol entry results in a move to more fee-based investment advisory business.

We also estimate specifications of the form:

$$
\begin{aligned}
& \{\text { Misconduct }\}_{\{i, t\}} \\
& =\beta_{\{1\}\{\text { Protocol }\}_{\{i, t-1\}}}+\beta_{\{1\}\{\text { Protocol } \times \text { Solicit }\}_{\{i, t-1\}}}+\gamma\{X\}_{\{i, t-1\}}+\delta_{i}+\delta_{F} \\
& +\delta_{\{c, t\}}+\epsilon_{\{i, t\}}
\end{aligned}
$$

and

$$
\{\text { Misconduct }\}_{\{i, t\}}=\beta_{\{1\}\{\text { Protocol }\}_{\{i, t-1\}}}+\gamma\{X\}_{\{i, t-1\}}+\delta_{j}+\delta_{\{c, t\}}+\epsilon_{\{i, t\}}
$$

where Solicit equals one if the advisor works in California, Montana, North Dakota, or Oklahoma, the states with courts that are less favorable toward nonsolicitation agreements. Note, the main effect of Solicit is subsumed by the county-year effects. $j$ indicates a job spell (individual-firm pair). The job spell fixed effects control for any potential match-related effects and subsume the individual and firm fixed effects.

In Table 4, we test how the assignment of property rights affects advisors' incentives to engage in misconduct. The unit of observation is an individual-year. Protocol is an indicator variable equal to one once the financial advisory firm signs the protocol and zero otherwise. In 
Columns one through three, misconduct is measured using customer disputes as in Dimmock, Gerken, and Graham (2017). In Columns four through six, misconduct is measured using a broader definition that also includes criminal charges, terminations, and civil and regulatory actions as in Egan, Matvos, and Seru (2017). Standard errors are clustered by firm-year.

We find strong evidence that advisors take better care of relationships after their firms enter the protocol. In Column 1, we find that customer disputes drop by 29 basis points when advisors enter the protocol, which represents a $42 \%$ reduction relative to the baseline rate. Recall that the specification contains advisor, firm, and year-county fixed effects, so the reduction is relative to the advisor's own treatment of customers before entry into the protocol, to advisors at the firm before entry into the protocol, and to contemporaneous behavior by other advisors within the same county. In Column 2, we interact Protocol with an indicator variable for being located in a state with courts that are less favorable toward non-solicitation agreements. Since the enforcement of non-solicitation agreements is likely to be less stringent in these states, we would expect a more muted effect for advisors located in these states. Note, Protocol could still reduce the costs of litigation for advisors in these states. Consistent with this reasoning, we find a positive (but statistically insignificant) coefficient on the interaction of Protocol $\times$ Solicit, suggesting that the effects are mitigated in California, Montana, North Dakota, and Oklahoma.

In Column 3, we again estimate the specification, but now include job spell (advisor-firm) fixed effects to condition out any within-advisor variation in human capital due to match effects. In these tests, the effect of Protocol is estimated solely on those advisors that join a firm before it enters the protocol and remain with the firm after it enters the agreement, eliminating the effects of sorting employees based on contemporaneous protocol status. We find that the coefficient on Protocol is a statistically and economically significant -27 basis points. Even advisors that work 
for the same firm before and after the firm joins the protocol experience a drop in customer dispute rates when they have greater property rights in the customer relationship. In Columns 3 through 6 , we find similar results with the broader Egan, Matvos, and Seru (2017) measure. Of particular interest, in Column 5, Protocol $\times$ Solicit is statistically significant. In sum, these analyses provide support for the notion that advisors are more careful with an asset (client relationship) when they have more property rights (ability to solicit these customers upon exiting a firm).

\subsection{Human Capital Investment}

The transfer of client ownership through the protocol affects the value of the external labor market for the advisor. The ability to transfer existing clients, rather than starting a book of business over, decreases the advisor's cost to exit and increases the value of the advisor for firms looking to poach talent. This result yields several testable implications with regard to the advisor's investment in human capital. We hypothesize that following their employer's joining of the protocol, advisors will increase their own human capital production in an effort to become more attractive to external firms. Further, we expect these increases to be stronger with regard to general human capital, given that it can be transferred within the industry, and weaker in regard to firm-specific capital that is not perfectly transferable. Further, we expect these incentives to be weaker in states that do not allow non-solicitation agreements.

We do not observe actual effort at the advisor level. We are unable to observe, for example, how many additional meetings they take, how many additional hours they work, or the change in the performance or size of their accounts. As such, we must use a proxy for human capital investment that is observable at the advisor level and is standardized across firms and across geographic region. We use FINRA's qualification exams. FINRA administers a series of exams 
authorizing individuals to, among other things, sell securities, become investment advisors, and become principals (supervisors) in a firm. The exams are standardized across the industry and administered at national testing centers.

\subsection{Industry Licenses}

We focus on two sets of exams in particular: the investment advisor exam (Series 65 or Series 66) and the general securities principal exam (Series 24). We do this for two reasons. First, these exams are commonly taken by experienced employees, allowing us to test how protocol inclusion shifts existing employee behavior. Second, these exams allows us to separately test for general versus firm-specific human capital production. The job profile of an investment advisor at UBS and Merrill Lynch is similar, and thus the effort from attaining a Series 65 license can transfer easily across the industry. This transfer of knowledge for a principal (Series 24) is less clear. Firms typically have specific policies and procedures that they require their principals to learn and follow. Further, firms may prefer to promote principals from within, as these employees are likely to be more familiar with the firm's culture, making their investment in supervisor capital less transferable. Consistent with this conjecture, in unreported tests, we find that after controlling for industry tenure, individual, time, and geographic effects, principals are less likely to move to a new firm than non-principals are.

In Table 5, we follow an approach identical to that of Models 2, 3, and 4 but replace misconduct with the employee's decision to earn an investment advisor license (Columns 1-3) or a principal's license (Columns 4-6). We find strong evidence that employees increase human capital after their firm enters the protocol. In Column 1, we find that the odds that an employee becomes an investment advisor increase by 94 basis points after entering the protocol, which 
represents a $27 \%$ increase relative to the baseline rate. As in Table 4 , the specification contains advisor, firm, and year-county fixed effects, so the increase is measured relative to the advisor's own treatment before entry into the protocol, to advisors at the firm before entry into the protocol, and to contemporaneous behavior by other advisors within the same county. In Column 2, we interact Protocol with an indicator variable for being located in a state with courts that are less favorable toward non-solicitation agreements. While the coefficient on the protocol's main effect remains positive, we find a negative coefficient on the interaction of Protocol $\times$ Solicit, suggesting that the effect is smaller in California, Montana, North Dakota, and Oklahoma.

In Column 3, we include job spell (advisor-firm) fixed effects to condition out any withinadvisor variation in human capital due to match effects. As in Table 4, the effect of Protocol here is estimated solely on those advisors that join a firm before the firm enters the protocol and remain with the firm after the firm enters the agreement, eliminating the effects of sorting of employees based on contemporaneous protocol status. We find that the coefficient on Protocol is a statistically and economically significant 76 basis points. Even among advisors that work for the same firm before and after the firm joins the protocol, these employees are more likely to add an investment advisory license.

In Columns 4-6, we turn to the effect of protocol inclusion on firm-specific human capital. We find that after their firm enters the protocol, employees are less likely to earn a principal's license. In Column 4, we find that the odds that an employee becomes a principal decrease by 111 basis points after entering the protocol, which represents a $51 \%$ decrease relative to the baseline rate. We find that this effect is dampened in states that are less favorable toward non-solicitation agreements and that these results hold when we include job spell (advisor-firm) fixed effects to condition out any within-advisor variation in human capital. 
To summarize, we find that protocol inclusion not only affects the employee's decision to invest in human capital, it also shifts their decision in the type of capital they invest in. Following their employer's joining of the protocol, employees increase human capital that transfers more easily within the industry and reduce their investment in firm-specific human capital.

\subsubsection{Testing Scores}

One further advantage of using industry licenses as a proxy for human capital investment is that for the Series 65 and Series 66 exams, we can observe the advisors' actual exam scores. This observation allows us to test for changes in human capital on the intensive margin. For these exams, we observe each time the employee sat for the exam, what score they received, and whether or not they passed. In Table 6, we examine each advisor's score on their initial attempt of the exam. We control for the advisor's industry experience, their other industry licenses, and firm and year fixed effects. Our variable of interest is Protocol, which captures whether the advisor's employer was in the protocol at the time the exam was taken. In Columns 1 and 2, we test for scores on the Series 66 exam, and in Columns 3 and 4, we test for scores on the Series 65 exam (we explain the differences between the two tests below).

From Column 1, we find that advisors that are in the protocol score 1.08 points higher (out of 100 possible points)on their Series 66 exam. Conversations with several advisors indicate that outright score may not be a meaningful measure of effort. Conditional on passing the exam, employers do not reward advisors for scoring higher. As such, in Column 2, we use a linear probability model to test whether protocol inclusion is associated with a higher pass rate for advisors. We find that advisors in the protocol are 5.05\% more likely to pass Series 66, a meaningful increase given that the baseline pass rate of the exam is $71 \%$. 
The use of the Series 66 exam is relatively new to the industry. The goal of its introduction was to combine the investment advisor's exam (Series 65) with the securities agent state law exam (Series 63). As the Series 63 is required to begin practice in most states, the Series 66 effectively serves as an investment advisor's exam for employees that are new to the industry. ${ }^{12}$ The Series 65 exam was the original investment advisory exam for the industry. The exam is typically taken by experienced brokers that already hold their Series 63 license and are looking to change their business model from a commission-based, transactional one to a long-term, fee-based one. In our data, the median industry experience of candidates sitting for the Series 66 and Series 65 exams is one year and seven years, respectively. As such, performance on the Series 65 exam allows us to test for changes in human capital on the intensive margin for experienced brokers.

Turning to Columns 3 and 4 of Table 6, we find that test performance on the Series 65 exam is higher for brokers that work for firms in the protocol. An experienced broker that sits for the Series 65 exam is $3.33 \%$ more likely to pass the exam if his employer is in the protocol. The baseline pass rate in our data is $72.5 \%$. In sum, we find that protocol inclusion affects an advisor's investment in human capital. Advisors are more likely to shift their investment away from firmspecific human capital that is difficult to transfer within the industry and toward general human capital that is easily transferred among firms. These effects are found at both the extensive and intensive margins.

\section{Firm Outcomes}

In this section, we examine the firm-level consequences for firms joining the protocol. One implication of using firm-level analysis is that our identification is not as clean as in the individual

\footnotetext{
${ }^{12}$ Colorado, the District of Columbia, Florida, Louisiana, Maryland, Ohio, and Puerto Rico do not require the Series
} 63 exam. 
level tests, and the estimates should be interpreted with this caveat in mind. If firms that join the protocol experience improved performance after membership, a natural question to ask is, why do not all firms choose to join? One possibility is that a firm may fear it will lose more human capital through the exit of its current advisors than it will gain from attracting new advisors. This possibility is highlighted by the case of Wachovia Sec., LLC v. Stanton: "Where both parties are signatories, they have essentially agreed to reciprocal poaching of registered representatives and the registered representative's clients from the former firm, apparently on the assumption that they will gain as much as they lose in the exchange." However, as we document earlier, the protocol is not necessarily a zero-sum game. While the loss of every advisor that leaves one protocol firm for another is exactly offset by the gain at the poaching firm, the allocation of property rights encourages advisor effort, and therefore protocol firms as a whole can be better off even if they have no net gain through movement of advisors within the protocol. A related point is that protocol membership can make these firms more attractive to nonprotocol advisors, so that membership increases the ability to recruit high-quality advisors.

We examine the question of whether firm performance improves after firms become protocol members. We use firm-level data from X-17 FOCUS reports (which report revenues and assets only of the filing subsidiary) and Form ADV (which reports assets under management and number of accounts for the entire investment advisory firm). We again estimate a specification following equation (1), now where $Y$ are various firm-level measures of output, $F$ indicates a financial advisory firm, and $t$ indicates year. As inclusion in the protocol has a strong effect on employee recruiting, we estimate this specification both with and without including the logarithm of number of employees in $\{X\}_{\{i, t-1\}}$ to examine both absolute changes and changes controlling for the growth of employees. 
Table 7 reports regression results from these analyses. In all specifications, we include both firm and year fixed effects. The firm effects help control for any time-invariant reporting differences between firms. In Panel A, we do not control for the number of employees, so the results should be interpreted in light of this. We find evidence that firms experience significantly higher revenues after joining the protocol. We similarly find evidence that assets under management and number of client accounts increase after protocol membership. In Panel B, we control for the number of employees to tease apart the growth due to increased head count and other factors (like increased productivity). In these specifications, we find that revenues increased by $6 \%$ (though the coefficient is not statistically significant), assets under management increased by $29.7 \%$, and accounts increased by $46.6 \%$ after protocol membership. ${ }^{13}$ We interpret these finding as consistent with protocol membership enhancing individual advisor performance.

\section{Conclusion}

In this paper, we have evaluated a firm's decision to voluntarily increase an employee's claim on his or her human capital, transforming investment in client relationships from a firm-specific to a general asset. In doing so, the firm's choice to join the protocol increases the employee's labor mobility. While inclusion in the protocol hastens employee departure from the firm, it also increases the employees' investment in their human capital. We find that advisors at protocol firms take better care of their client relationships, as evidenced by a drop in customer dispute rates upon their employer's joining the protocol. Advisors also increase their number of industry licenses and shift their business from a shorter-term, commission-based model to a longer-term, fee-based model. Our ability to utilize job spell, time, and geography fixed effects allows us to rule out

\footnotetext{
${ }^{13}$ We use the approach in Kennedy (1981) and assume normal errors.
} 
alternative conclusions such as selection bias and local economic effects. Combining the effects of increased effort from existing employees and firms' ability to poach talent from competing firms, we find that upon joining the protocol, firms increase assets under management and the number of accounts they handle. Our findings provide empirical support for property rights-based investment theories of human capital. 


\section{Appendix: Official Text of the Protocol for Broker Recruiting}

The principal goal of the following protocol is to further the clients' interests of privacy and freedom of choice in connection with the movement of their Registered Representatives ("RRs") between firms. If departing RRs and their new firm follow this protocol, neither the departing RR nor the firm that he or she joins would have any monetary or other liability to the firm that the RR left by reason of the RR taking the information identified below or the solicitation of the clients serviced by the RR at his or her prior firm, provided, however, that this protocol does not bar or otherwise affect the ability of the prior firm to bring an action against the new firm for "raiding." The signatories to this protocol agree to implement and adhere to it in good faith.

When RRs move from one firm to another and both firms are signatories to this protocol, they may take only the following account information: client name, address, phone number, email address, and account title of the clients that they serviced while at the firm ("the Client Information") and are prohibited from taking any other documents or information. Resignations will be in writing delivered to local branch management and shall include a copy of the Client Information that the RR is taking with him or her. The RR list delivered to the branch also shall include the account numbers for the clients serviced by the RR. The local branch management will send the information to the firm's back office. In the event that the firm does not agree with the RR's list of clients, the RR will nonetheless be deemed in compliance with this protocol so long as the RR exercised good faith in assembling the list and substantially complied with the requirement that only Client Information related to clients he or she serviced while at the firm be taken with him or her.

To ensure compliance with GLB and SEC Regulation S-P, the new firm will limit the use of the Client Information to the solicitation by the RR of his or her former clients and will not 
permit the use of the Client Information by any other RR or for any other purpose. If a former client indicates to the new firm that he/she would like the prior firm to provide account number(s) and/or account information to the new firm, the former client will be asked to sign a standardized form authorizing the release of the account number(s) and/or account information to the new firm before any such account number(s) or account information are provided.

The prior firm will forward to the new firm the client's account number(s) and/or most recent account statement(s) or information concerning the account's current positions within one business day, if possible, but, in any event, within two business days, of its receipt of the signed authorization. This information will be transmitted electronically or by fax, and the requests will be processed by the central back office rather than the branch where the RR was employed. A client who wants to transfer his/her account need only sign an Automated Customer Account Transfer (ACAT) form.

RRs that comply with this protocol would be free to solicit customers that they serviced while at their former firms, but only after they have joined their new firms. A firm would continue to be free to enforce whatever contractual, statutory or common law restrictions exist on the solicitation of customers to move their accounts by a departing RR before he or she has left the firm.

The RR's former firm is required to preserve the documents associated with each account as required by SEC regulations or firm record retention requirements.

It shall not be a violation of this protocol for an $\mathrm{RR}$, prior to his or her resignation, to provide another firm with information related to the RR's business, other than account statements, so long as that information does not reveal client identity. 
Accounts subject to a services agreement for stock benefits management services between the firm and the company sponsoring the stock benefit plan that the account holder participates in (such as with stock option programs) would still be subject to (a) the provisions of that agreement as well as to (b) the provisions of any account servicing agreement between the RR and the firm. Also, accounts subject to a participation agreement in connection with prospecting individual retirement account (IRA) rollover business would still be subject to the provisions of that agreement.

If an RR is a member of a team or partnership, and where the entire team/partnership does not move together to another firm, the terms of the team/partnership agreement will govern for which clients the departing team members or partners may take Client Information and which clients the departing team members or partners can solicit. In no event, however, shall a team/partnership agreement be construed or enforced to preclude an RR from taking the Client Information for those clients whom he or she introduced to the team or partnership or from soliciting such clients.

In the absence of a team or partnership written agreement on this point, the following terms shall govern where the entire team is not moving: (1) If the departing team member or partner has been a member of the team or partnership in a producing capacity for four years or more, the departing team member or partner may take the Client Information for all clients serviced by the team or partnership and may solicit those clients to move their accounts to the new firm without fear of litigation from the RR's former firm with respect to such information and solicitations; (2) If the departing team member or partner has been a member of the team or partnership in a producing capacity for less than four years, the departing team member or partner will be free from 
litigation from the RR's former firm with respect to client solicitations and the Client Information only for those clients that he or she introduced to the team or partnership.

If accounts serviced by the departing RR were transferred to the departing RR pursuant to a retirement program that pays a retiring $R R$ trailing commissions on the accounts in return for certain assistance provided by the retiring RR prior to his or her retirement in transitioning the accounts to the departing RR, the departing RR's ability to take Client Information related to those accounts and the departing RR's right to solicit those accounts shall be governed by the terms of the contract between the retiring $R R$, the departing $R R$, and the firm with which both were affiliated.

A signatory to this protocol may withdraw from the protocol at any time and shall endeavor to provide 10 days' prior written notice of its withdrawal to all other signatories hereto. A signatory who has withdrawn from the protocol shall cease to be bound by the protocol and the protocol shall be of no further force or effect with respect to the signatory. The protocol will remain in full force and effect with respect to those signatories who have not withdrawn. 


\section{References}

Baker, George P., and Thomas N. Hubbard., 2004, Contractibility and asset ownership: On-board computers and governance in U.S. trucking, Quarterly Journal of Economics 119, 14431479.

Barnett, Jonathan M., and Ted M. Sichelman, 2016, Revisiting labor mobility in innovation markets Working Paper, University of Southern California Law School.

Bergstresser, Daniel, John Chalmers, and Peter Tufano, 2009, Assessing the costs and benefits of brokers in the mutual fund industry, Review of Financial Studies 22, 4129-4156.

Chalmers, John, and Jonathan Reuter, 2015, Is conflicted investment advice better than no advice?, NBER Working Paper 18158 .

Charoenwong, Ben, Alan Kwan, and Tarik Umar, 2017, Who should regulate investment advisors?, Working Paper, Hong Kong University.

Correia, Sergio, 2015, Singletons, cluster-robust standard errors and fixed effects: A bad mix Working Paper, Duke University.

Dimmock, Stephen G, William C Gerken, and Nathaniel P. Graham, 2017, Is fraud contagious? Career network and fraud by financial advisors, Journal of Finance forthcoming.

Egan, Mark, Gregor Matvos, and Amit Seru, 2017, The market for financial adviser misconduct, Journal of Political Economy forthcoming.

Foerster, Stephen, Juhani T. Linnainmaa, Brian T. Melzer, and Alessandro Previtero, 2017, Retail financial advice: Does one size fit all?, Journal of Finance 72, 1441-1482.

Garmaise, Mark J., 2011, Ties that truly bind: Noncompetition agreements, executive compensation, and firm investment, Journal of Law, Economics and Organization 27, 376425.

Gennaioli, Nicola, Andrei Shleifer, and Robert Vishny, 2015, Money doctors, Journal of Finance 70, 91-114.

Georgarakos, Dimitris, and Roman Inderst, 2014, Financial advice and stock market participation, Working Paper.

Gilson, Ronald J., 1999, The legal infrastructure of high technology industrial districts: Silicon valley, Route 128, and covenants not to compete, New York University Law Review 74, 575-629.

Grossman, Sanford J., and Oliver D. Hart, 1986, The costs and benefits of ownership: A theory of vertical and lateral integration, Journal of Political Economy 94, 691-719.

Hackethal, Andreas, Michael Haliassos, and Tullio Jappelli, 2012, Financial advisors: A case of babysitters?, Journal of Banking \& Finance 36, 509-524.

Hart, Oliver, and John Moore, 1990, Property rights and the nature of the firm, Journal of Political Economy 98, 1119-1158.

Hoechle, Daniel, Stefan Ruenzi, Nic Schaub, and Markus Schmid, forthcoming, The impact of 
financial advice on trade performance and behavioral biases, Review of Finance .

Hung, Angela A., Noreen Clancy, Jeff Dominitz, Eric Talley, Claude Berribi, and Farrukh Suvankulov, 2008, Investor and industry perspectives on investment advisors and brokerdealers, Technical Report RAND Center for Corporate Ethics and Governance.

Jeffers, Jessica S., 2017, The impact of restricting labor mobility on corporate investment and entrepreneurship Working Paper, University of Chicago.

Kennedy, Peter E., 1981, Estimation with correctly interpreted dummy variables in semilogarithmic equations, American Economic Review 71, 801.

Lavetti, Kurt, Carol Simon, and William White, 2017, The impacts of restricting mobility of skilled service workers: Evidence from physicians, Working Paper, Ohio State University.

Massa, Massimo, Jonathan Reuter, and Eric Zitzewitz, 2010, When should firms share credit with employees? Evidence from anonymously managed mutual funds, Journal of Financial Economics 95, 400-424.

Mullainathan, Sendhil, Markus Noeth, and Antoinette Schoar, 2012, The market for financial advice: An audit study, NBER Working Paper 17929.

Simester, Duncan I., and Birger Wernerfelt, 2005, Determininants of asset ownership: A study of the carpentry trade, Review of Economics and Statistics 87, 50-58.

Williamson, Oliver E., 1979, Transaction-cost economics: The governance of contractual relationship, Journal of Law and Economics 22, 233-261. 


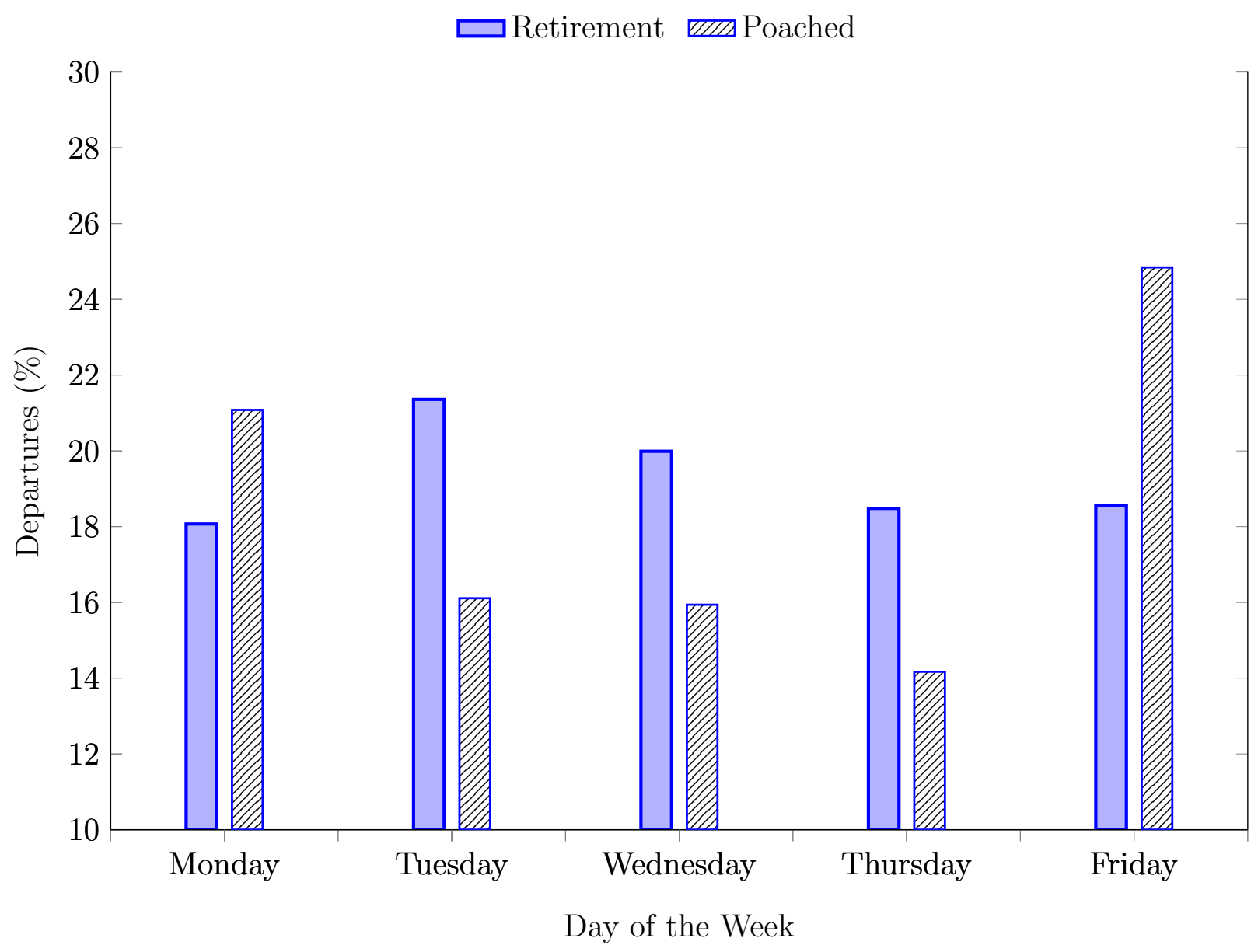

Figure 1

Advisor Departure by Day of the Week 


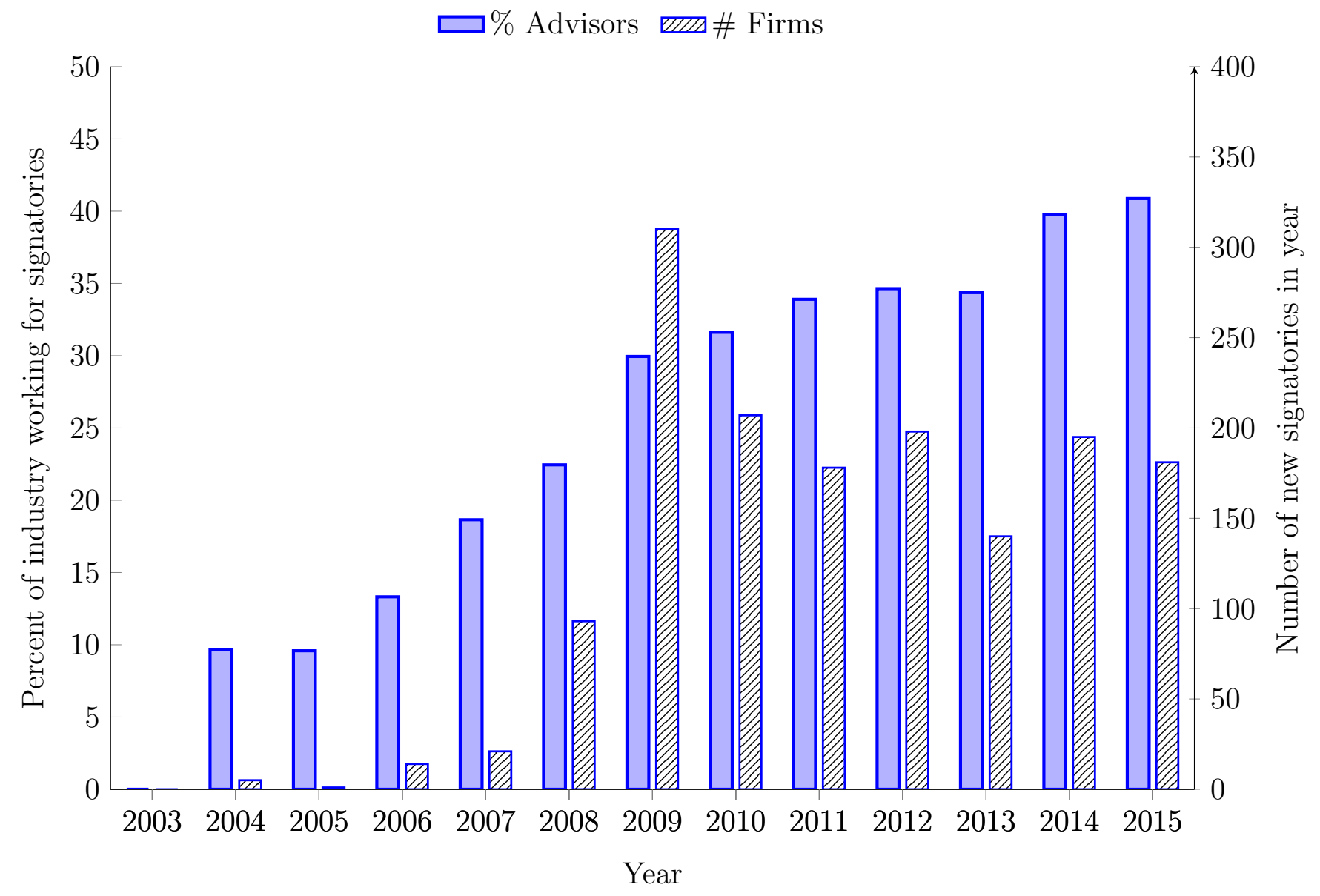

Figure 2

Broker Protocol Inclusion by Year 


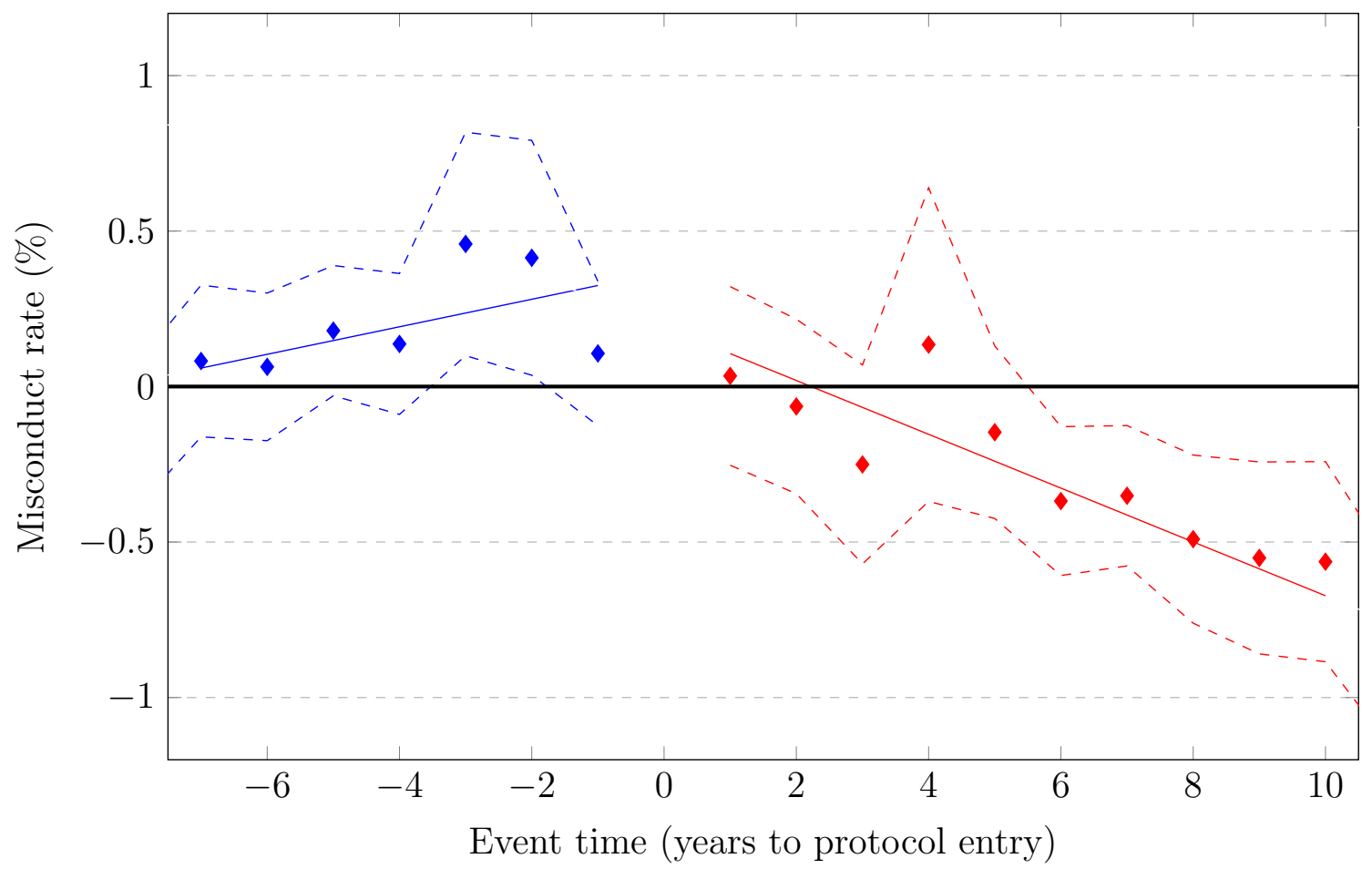

Figure 3

Misconduct Rates by Years to Broker Protocol Treatment

Misconduct $_{i, t}=\sum_{k} \beta_{k}\left(\right.$ Protocol $_{i} \times$ years to treatment $)+\gamma \mathbf{X}_{i, t-1}+\delta_{i}+\delta_{F}+\delta_{c, t}+\epsilon_{i, t}$ 


\section{Table 1}

\section{Signatories of the Broker Protocol}

This table reports the name and signatory date of large financial advisory firms ( $>1,000$ employees) entering the Protocol during our sample period.

\begin{tabular}{lrlr}
\hline Firm Name & Date & Firm Name & Date \\
\hline UBS Financial Services Inc. & 18-Aug-04 & Woodbury Financial Services Inc. & 7-Apr-09 \\
Merrill Lynch, Pierce, Fenner \& Smith & 18-Aug-04 & Morgan Stanley Smith Barney LLC & 1-Jun-09 \\
Smith Barney & 18-Aug-04 & FSC Securities Corp. & 5-Jun-09 \\
Wachovia Securities LLC & 10-Jan-06 & Royal Alliance Associates Inc. & 5-Jun-09 \\
Wells Fargo Advisors LLC & 10-Jan-06 & SagePoint Financial Inc. & 5-Jun-09 \\
Raymond James \& Associates Inc. & 31-Jul-06 & Ameriprise Financial Services Inc. & 11-Jun-09 \\
Morgan Stanley \& Co. Inc. & 6-Oct-06 & Lincoln Financial Securities Corp. & 31-Aug-09 \\
Jefferies \& Company Inc. & 15-Feb-07 & Waddell \& Reed Inc. & 12-Mar-10 \\
A.G. Edwards \& Sons Inc. & 1-Mar-07 & Transamerica Financial Advisors Inc. & 1-Dec-10 \\
Cambridge Investment Research Inc. & 2-Mar-07 & Ameritas Investment Corp. & 14-Dec-11 \\
Purshe Kaplan Sterling Investments Inc. & 9-Mar-07 & U.S. Bancorp Investments Inc. & 6-Feb-12 \\
Credit Suisse Securities USA LLC & 20-Nov-07 & Robert W. Baird \& Co. & 2-Apr-12 \\
RBC Capital Markets Corp. & 1-Jul-08 & Securities America Inc. & 28-Dec-12 \\
Stifel Nicolaus \& Company Inc. & 7-Aug-08 & JP Morgan Securities LLC & 6-Feb-14 \\
LPL Financial Corp. & 4-Sep-08 & Park Avenue Securities LLC & 7-Aug-14 \\
Janney Montgomery Scott LLC & 7-Nov-08 & Hornor, Townsend \& Kent Inc. & 31-Oct-14 \\
National Planning Corp. & $25-$ Nov-08 & SunTrust Investment Services Inc. & 19-Nov-14 \\
Oppenheimer \& Co. Inc. & 12-Feb-09 & MetLife Securities Inc. MSI & 7-Jan-15 \\
Next Financial Group Inc. & 9-Mar-09 & Financial Network Investment Corp. & 11-Jan-16 \\
Morgan Keegan \& Company Inc. & 16-Mar-09 & Cetera Advisors LLC & 11-Jan-16 \\
Tower Square Securities Inc. & $27-$ Mar-09 & Multi-Financial Securities Corp. & 11-Jan-16 \\
Walnut Street Securities Inc. & $27-$ Mar-09 & First Allied Securities Inc. & 11-Jan-16 \\
NFP Advisor Services LLC & 2-Apr-09 & ProEquities Inc. & 30-Nov-16 \\
\hline
\end{tabular}




\section{Table 2}

\section{Summary Statistics}

This table summarizes individual financial advisor and financial advisory firm-level data for observations in the final year of the sample. In Panel A, individual data is obtained from FINRA's BrokerCheck and is reported as of the last year of the sample. Experience is defined as number of years since entry into the industry. Customer Disputes and Total Misconduct (including criminal charges, terminations, civil and regulatory actions) are calculated from the BrokerCheck disclosures. Standard errors are clustered by firm-year. We report sample means for Protocol and Non-Protocol advisors, and the difference. In Panel B, firm-level data are supplemented with data from Form BD (number of business lines and states of registration), FOCUS X-17 reports (revenues), and Form ADV (AUM and accounts) and is reported as of the last year of the sample. We report sample means for Protocol and Non-Protocol advisors, and their differences. ${ }^{* * *}, * *$, and $*$ indicate statistical significance at the $1 \%, 5 \%$, and $10 \%$ levels, respectively.

Panel A: Individual-Level Summary Statistics

\begin{tabular}{lcccc}
\hline & Protocol & Non-Protocol & Difference & \\
\hline \# of Firms in Career & 2.3 & 1.9 & 0.4 & $* * *$ \\
Experience & 16.4 & 13.6 & 2.8 & $* * *$ \\
Customer Dispute & $7.0 \%$ & $2.5 \%$ & $4.5 \%$ & $* * *$ \\
Total Misconduct & $10.1 \%$ & $5.9 \%$ & $4.2 \%$ & $* * *$ \\
Series 6 & $26.2 \%$ & $44.2 \%$ & $-18.0 \%$ & $* * *$ \\
Series 7 & $81.0 \%$ & $61.6 \%$ & $19.5 \%$ & $* * *$ \\
Series 63 & $70.7 \%$ & $74.8 \%$ & $-4.1 \%$ & \\
Series 65 & $27.7 \%$ & $13.9 \%$ & $13.8 \%$ & $* * *$ \\
Series 66 & $31.9 \%$ & $19.9 \%$ & $12.0 \%$ & $* * *$ \\
Series 24 & $13.9 \%$ & $14.8 \%$ & $-0.9 \%$ & \\
\hline
\end{tabular}

Panel B: Firm-Level Summary Statistics

\begin{tabular}{lcccl}
\hline & Protocol & Non-Protocol & Difference & \\
\hline \# Employees & $1,213.6$ & 100.1 & $1,113.5$ & $* * *$ \\
Number of business lines & 13.4 & 5.8 & 7.6 & $* * *$ \\
Number of states registered & 39.1 & 14.3 & 24.8 & $* * *$ \\
AUM (millions) & $\$ 23,072$ & $\$ 3,016$ & $\$ 20,056$ & $* * *$ \\
\# Accounts & $88,617.2$ & $6,994.2$ & $81,622.9$ & $* * *$ \\
Revenues (millions) & $\$ 245$ & $\$ 13$ & $\$ 232$ & $* * *$ \\
\hline
\end{tabular}


Table 3

\section{Brokerage Firm Employment and Turnover from Joining the Protocol}

We model financial advisory firms' change in employee headcount of experienced employees ( $>1$ year industry experience) as a function of entering the Protocol. The unit of observation is a firm-year. Poaching (Departing) is a count variable of hiring (losing) experienced brokers. In columns 2 (5) and 3 (6), we separately estimate whether the poaching (departing) occurs from (for) a Protocol or Non-Protocol firm. In Model 7, we estimate how many of the departing employees leave to start their own firms. Standard errors are clustered at the firm and year levels. ***,**, and * indicate statistical significance at the 1\%, 5\%, and $10 \%$ level, respectively.

\begin{tabular}{|c|c|c|c|c|c|c|c|}
\hline & $\begin{array}{c}1 \\
\text { Poaching }\end{array}$ & $\begin{array}{c}2 \\
\text { Poaching from BP }\end{array}$ & $\begin{array}{c}3 \\
\text { Poaching from non-BP }\end{array}$ & $\begin{array}{c}4 \\
\text { Departing }\end{array}$ & $\begin{array}{c}5 \\
\text { Departing to BP }\end{array}$ & $\begin{array}{c}6 \\
\text { Departing to non-BP }\end{array}$ & $\begin{array}{c}7 \\
\text { Start Own Firm }\end{array}$ \\
\hline Protocol & $\begin{array}{c}13.849^{* *} \\
{[2.22]}\end{array}$ & $\begin{array}{c}16.511^{* * *} \\
{[5.03]}\end{array}$ & $\begin{array}{c}-7.906^{* * *} \\
{[-3.10]}\end{array}$ & $\begin{array}{c}9.290^{*} \\
{[1.82]}\end{array}$ & $\begin{array}{c}9.480^{* *} \\
{[2.58]}\end{array}$ & $\begin{array}{c}-10.915^{* * *} \\
{[-3.20]}\end{array}$ & $\begin{array}{c}2.165^{*} \\
{[1.82]}\end{array}$ \\
\hline Log \# Employees & $\begin{array}{c}8.498^{* * *} \\
{[6.57]}\end{array}$ & $\begin{array}{c}1.206^{* * *} \\
{[4.27]}\end{array}$ & $\begin{array}{c}4.573^{* * *} \\
{[6.56]}\end{array}$ & $\begin{array}{c}10.405^{* * *} \\
{[6.40]}\end{array}$ & $\begin{array}{c}1.535^{* * *} \\
{[3.64]}\end{array}$ & $\begin{array}{c}7.801^{* * *} \\
{[6.50]}\end{array}$ & $\begin{array}{c}0.618^{* * *} \\
{[5.00]}\end{array}$ \\
\hline Log Experience & $\begin{array}{l}-0.361 \\
{[-0.51]}\end{array}$ & $\begin{array}{l}-0.236 \\
{[-1.36]}\end{array}$ & $\begin{array}{l}0.313 \\
{[1.15]}\end{array}$ & $\begin{array}{l}0.186 \\
{[0.27]}\end{array}$ & $\begin{array}{l}-0.313 \\
{[-1.09]}\end{array}$ & $\begin{array}{c}1.007^{* *} \\
{[2.29]}\end{array}$ & $\begin{array}{c}0.174^{* * *} \\
{[4.02]}\end{array}$ \\
\hline Firm FE & $\mathrm{Y}$ & $\mathrm{Y}$ & $\mathrm{Y}$ & $\mathrm{Y}$ & $\mathrm{Y}$ & $\mathrm{Y}$ & $\mathrm{Y}$ \\
\hline Year FE & $\mathrm{Y}$ & $\mathrm{Y}$ & $\mathrm{Y}$ & $\mathrm{Y}$ & $\mathrm{Y}$ & $\mathrm{Y}$ & $\mathrm{Y}$ \\
\hline Observations & 77,341 & 77,341 & 77,341 & 77,341 & 77,341 & 77,341 & 77,341 \\
\hline R-squared & 0.836 & 0.667 & 0.801 & 0.664 & 0.609 & 0.524 & 0.831 \\
\hline
\end{tabular}




\section{Table 4}

\section{Client Relationships: Customer Disputes and Misconduct}

We test how the assignment of property rights affects advisors' incentives to protect client relationships and avoid misconduct. The unit of observation is an individual-year. Protocol is an indicator variable equal to one once the advisory firm signs the Protocol and zero otherwise. Solicit equals one in states with courts that are less favorable to non-solicit agreements: California, North Dakota, Montana, and Oklahoma. In Columns 1 through 3, the dependent variable is an indicator for customer disputes in a given advisor-year. In Columns 4 through 6 , the dependent variable is misconduct which includes criminal charges, terminations, civil and regulatory actions in addition to customer disputes. Standard errors are clustered by firm-year. ***,**, and * indicate statistical significance at the $1 \%, 5 \%$, and $10 \%$ levels, respectively.

\begin{tabular}{lcccccc}
\hline & 1 & 2 & 3 & 4 & 5 & 6 \\
\hline Protocol & $-0.0029^{* * *}$ & $-0.0030^{* * *}$ & $-0.0027^{* *}$ & $-0.0028^{* * *}$ & $-0.0030^{* * *}$ & $-0.0024^{*}$ \\
& {$[-2.880]$} & {$[-3.042]$} & {$[-2.306]$} & {$[-2.736]$} & {$[-3.025]$} & {$[-1.936]$} \\
Protocol $\times$ Solicit & & 0.0008 & & & $0.0019^{* *}$ & \\
Log Experience & & {$[1.193]$} & & & {$[2.431]$} & \\
& $0.0076^{* * *}$ & $0.0076^{* * *}$ & $0.0057^{* * *}$ & $0.0097^{* * *}$ & $0.0097^{* * *}$ & $0.0077^{* * *}$ \\
Series 63 & {$[19.273]$} & {$[19.273]$} & {$[13.010]$} & {$[21.227]$} & {$[21.233]$} & {$[14.736]$} \\
& $-0.0011^{* * *}$ & $-0.0011^{* * *}$ & $-0.0009^{* * *}$ & $-0.0015^{* * *}$ & $-0.0015^{* * *}$ & $-0.0011^{* * *}$ \\
Series 6 & {$[-5.641]$} & {$[-5.641]$} & {$[-3.828]$} & {$[-6.443]$} & {$[-6.443]$} & {$[-3.685]$} \\
& $-0.0039^{* * *}$ & $-0.0039^{* * *}$ & $-0.0025^{* * *}$ & $-0.0040^{* * *}$ & $-0.0040^{* * *}$ & $-0.0025^{* * *}$ \\
Series 7 & {$[-11.219]$} & {$[-11.219]$} & {$[-6.525]$} & {$[-7.314]$} & {$[-7.314]$} & {$[-3.666]$} \\
& $0.0015^{* * *}$ & $0.0014^{* * *}$ & $0.0016^{* * *}$ & $0.0009^{* * *}$ & $0.0009^{* * *}$ & $0.0017^{* * *}$ \\
Other Exams & {$[5.598]$} & {$[5.590]$} & {$[4.984]$} & {$[3.174]$} & {$[3.156]$} & {$[4.542]$} \\
Series 24 & $-0.0006^{* * *}$ & $-0.0006^{* * *}$ & $-0.0007^{* * *}$ & $-0.0007^{* * *}$ & $-0.0007^{* * *}$ & $-0.0009^{* * *}$ \\
& {$[-4.002]$} & {$[-3.999]$} & {$[-3.215]$} & {$[-4.220]$} & {$[-4.214]$} & {$[-4.091]$} \\
Investment Adviser & 0.0000 & 0.0000 & -0.0001 & -0.0005 & -0.0005 & $-0.0008^{* *}$ \\
& {$[0.147]$} & {$[0.146]$} & {$[-0.365]$} & {$[-1.569]$} & {$[-1.571]$} & {$[-2.422]$} \\
& $0.0028^{* * *}$ & $0.0028^{* * *}$ & $0.0024^{* * *}$ & $0.0032^{* * *}$ & $0.0032^{* * *}$ & $0.0029^{* * *}$ \\
Employee FE & {$[8.641]$} & {$[8.643]$} & {$[5.833]$} & {$[9.419]$} & {$[9.425]$} & {$[6.583]$} \\
Firm FE & $\mathrm{Y}$ & $\mathrm{Y}$ & subsumed & $\mathrm{Y}$ & $\mathrm{Y}$ & subsumed \\
Firm $\times$ Employee FE & $\mathrm{Y}$ & $\mathrm{Y}$ & subsumed & $\mathrm{Y}$ & $\mathrm{Y}$ & subsumed \\
Year $\times$ FIPS FE & - & - & $\mathrm{Y}$ & - & - & $\mathrm{Y}$ \\
\hline Observations & $\mathrm{Y}$ & $\mathrm{Y}$ & $\mathrm{Y}$ & $\mathrm{Y}$ & $\mathrm{Y}$ & $\mathrm{Y}$ \\
R-squared & $9,234,609$ & $9,234,609$ & $8,819,308$ & $9,234,609$ & $9,234,609$ & $8,819,308$ \\
\hline & 0.146 & 0.146 & 0.239 & 0.165 & 0.165 & 0.256 \\
\hline
\end{tabular}




\section{Table 5}

\section{Advisor Propensity to Invest in Human Capital}

We model an individual advisor's decision to add an additional license/certification. The unit of observation is an employee-year. Protocol is an indicator variable equal to one once the advisory firm signs the Protocol and zero otherwise. Solicit equals one in states with courts that are less favorable to non-solicit agreements: California, North Dakota, Montana, and Oklahoma, and zero otherwise. In Columns 1 through 3, the dependent variable is an indicator for obtaining an investment advisor (Series 65 or Series 66) license. In Columns 4 through 6, the dependent variable is an indicator for obtaining a Principal (Series 24) license. Standard errors are clustered at the firm-year level. ***,**, and $*$ indicate statistical significance at the $1 \%, 5 \%$, and $10 \%$ levels, respectively.

\begin{tabular}{|c|c|c|c|c|c|c|}
\hline & 1 & 2 & 3 & 4 & 5 & 6 \\
\hline & \multicolumn{3}{|c|}{ Industry Specific } & \multicolumn{3}{|c|}{ Firm Specific } \\
\hline & IA & IA & IA & Series 24 & Series 24 & Series 24 \\
\hline \multirow[t]{2}{*}{ Protocol } & $0.0094^{* * *}$ & $0.0099 * * *$ & $0.0076^{* *}$ & $-0.0111^{* * *}$ & $-0.0113^{* * *}$ & $-0.0081^{* * *}$ \\
\hline & [3.088] & [3.224] & {$[2.279]$} & {$[-5.941]$} & {$[-6.187]$} & {$[-4.589]$} \\
\hline \multirow[t]{2}{*}{ Protocol $\times$ Solicit } & & $-0.0041^{* *}$ & & & $0.0020^{*}$ & \\
\hline & & {$[-2.343]$} & & & {$[1.682]$} & \\
\hline \multirow[t]{2}{*}{ Log Experience } & $0.0126^{* * *}$ & $0.0126^{* * *}$ & $0.0196^{* * *}$ & $-0.0015^{*}$ & $-0.0015^{*}$ & $0.0021^{* *}$ \\
\hline & {$[6.577]$} & [6.575] & [7.654] & {$[-1.780]$} & {$[-1.779]$} & [2.048] \\
\hline \multirow[t]{2}{*}{ Series 63} & $-0.0336^{* * *}$ & $-0.0336^{* * *}$ & $-0.0290 * * *$ & $-0.0030 * * *$ & $-0.0030^{* * *}$ & $-0.0054^{* * *}$ \\
\hline & {$[-18.433]$} & {$[-18.437]$} & {$[-16.236]$} & {$[-3.044]$} & {$[-3.044]$} & {$[-5.338]$} \\
\hline \multirow[t]{2}{*}{ Series 6} & $0.0356^{* * *}$ & $0.0357 * * *$ & $0.0195^{* * *}$ & $-0.0135^{* * *}$ & $-0.0135^{* * *}$ & $-0.0079 * * *$ \\
\hline & {$[12.131]$} & {$[12.135]$} & {$[5.629]$} & {$[-12.654]$} & {$[-12.657]$} & {$[-6.950]$} \\
\hline \multirow[t]{2}{*}{ Series 7} & $0.1572^{* * *}$ & $0.1572 * * *$ & $0.1232^{* * *}$ & $0.0520 * * *$ & $0.0520 * * *$ & $0.0495 * * *$ \\
\hline & {$[44.826]$} & {$[44.830]$} & {$[33.022]$} & {$[28.636]$} & {$[28.639]$} & {$[25.363]$} \\
\hline \multirow[t]{2}{*}{ Other Exams } & $0.0193^{* * *}$ & $0.0193^{* * *}$ & $0.0121^{* * *}$ & $0.0340^{* * *}$ & $0.0340^{* * *}$ & $0.0218^{* * *}$ \\
\hline & {$[21.223]$} & {$[21.226]$} & {$[10.633]$} & {$[28.622]$} & {$[28.620]$} & {$[20.301]$} \\
\hline \multirow[t]{2}{*}{ Series 24} & $0.0200 * * *$ & $0.0200^{* * *}$ & $0.0155^{* * *}$ & & & \\
\hline & {$[14.667]$} & {$[14.670]$} & {$[8.751]$} & & & \\
\hline \multirow[t]{2}{*}{ Investment Adviser (IA) } & & & & $0.0024^{* * *}$ & $0.0024^{* * *}$ & -0.0013 \\
\hline & & & & {$[2.641]$} & {$[2.642]$} & {$[-1.343]$} \\
\hline Employee FE & $\mathrm{Y}$ & $\mathrm{Y}$ & subsumed & $\mathrm{Y}$ & $\mathrm{Y}$ & subsumed \\
\hline Firm FE & Y & $\mathrm{Y}$ & subsumed & $\mathrm{Y}$ & $\mathrm{Y}$ & subsumed \\
\hline Firm $\times$ Employee FE & - & - & $\mathrm{Y}$ & - & - & $\mathrm{Y}$ \\
\hline Year $\times$ FIPS FE & $\mathrm{Y}$ & $\mathrm{Y}$ & $\mathrm{Y}$ & Y & $\mathrm{Y}$ & $\mathrm{Y}$ \\
\hline Observations & $8,861,782$ & $8,861,782$ & $8,454,636$ & $8,861,782$ & $8,861,782$ & $8,454,636$ \\
\hline R-squared & 0.872 & 0.872 & 0.924 & 0.864 & 0.864 & 0.922 \\
\hline
\end{tabular}




\section{Table 6}

\section{FINRA License Test Scores}

We test how the assignment of property rights affects advisors' incentives to invest in their human capital. Here, we measure human capital through advisors' exam scores on the Series 65 and Series 66 exams. The unit of observation is an exam (individual-year). Standard errors are clustered at the firm-year level. ${ }^{* * *}, * *$, and $*$ indicate statistical significance at the $1 \%, 5 \%$, and $10 \%$ levels, respectivesly.

\begin{tabular}{lcccc}
\hline & \multicolumn{2}{c}{2} & \multicolumn{2}{c}{3} \\
& \multicolumn{2}{c}{ Series 66} & \multicolumn{2}{c}{ Series 65} \\
& Score & Pass $=1$ & Score & Pass $=1$ \\
\hline Protocol & $1.0790^{* * *}$ & $0.0505^{* * *}$ & 0.4810 & $0.0333^{* *}$ \\
& {$[4.437]$} & {$[3.989]$} & {$[1.235]$} & {$[2.002]$} \\
Log Experience & -0.0852 & -0.0025 & $0.8539^{* * *}$ & $0.0374^{* * *}$ \\
& {$[-0.658]$} & {$[-0.349]$} & {$[8.102]$} & {$[7.459]$} \\
Series 6 & 0.1376 & 0.0061 & -0.0125 & $0.0161^{* *}$ \\
& {$[1.170]$} & {$[0.858]$} & {$[-0.097]$} & {$[2.244]$} \\
Series 7 & $-0.7268^{* * *}$ & $-0.0324^{* * *}$ & $2.0683^{* * *}$ & $0.0981^{* * *}$ \\
& {$[-3.850]$} & {$[-3.079]$} & {$[13.003]$} & {$[11.748]$} \\
Series 24 & $1.9490^{* * *}$ & $0.0976^{* * *}$ & $1.3426^{* * *}$ & $0.0547^{* * *}$ \\
& {$[12.104]$} & {$[10.625]$} & {$[8.437]$} & {$[6.565]$} \\
Other Exams & $0.5951^{* * *}$ & $0.0224^{* * *}$ & $0.7778^{* * *}$ & $0.0348^{* * *}$ \\
& {$[7.065]$} & {$[4.780]$} & {$[11.018]$} & {$[9.293]$} \\
\hline Firm FE & $\mathrm{Y}$ & $\mathrm{Y}$ & $\mathrm{Y}$ & $\mathrm{Y}$ \\
Time FE & $\mathrm{Y}$ & $\mathrm{Y}$ & $\mathrm{Y}$ & $\mathrm{Y}$ \\
\hline Observations & 35,171 & 35,171 & 33,373 & 33,373 \\
R-squared & 0.082 & 0.059 & 0.151 & 0.108 \\
\hline
\end{tabular}




\section{Table 7}

\section{Advisory Firm Effects from Joining The Protocol}

We model the effect on financial advisory firms' operations following their decision to join the Protocol. Protocol is an indicator variable equal to one once the advisory firm signs the Protocol and zero otherwise. In Column 1, the dependent variable is the revenues reported on the firm's FOCUS filing. In Column 2, the dependent variable is the logarithm of assets under management reported on the firm's Form ADV filing. In Column 3, the dependent variable is the logarithm of number of client accounts reported on the firm's Form ADV filing. The unit of observation is a firm-year. Standard errors are clustered at firm and year level. $* * *, * *$, and $*$ indicate statistical significance at the $1 \%, 5 \%$, and $10 \%$ levels, respectively.

Panel A: Baseline

\begin{tabular}{lccc}
\hline & $\log$ (Revenue) & $\log (\mathrm{AUM})$ & $\log ($ Accounts $)$ \\
\hline Protocol & $0.508^{* * *}$ & $0.378^{* * *}$ & $0.520^{* * *}$ \\
& {$[3.87]$} & {$[4.06]$} & {$[4.76]$} \\
\hline Firm FE & $\mathrm{Y}$ & $\mathrm{Y}$ & $\mathrm{Y}$ \\
Year FE & $\mathrm{Y}$ & $\mathrm{Y}$ & $\mathrm{Y}$ \\
\hline Observations & 32,472 & 6,815 & 6,816 \\
R-squared & 0.770 & 0.866 & 0.875 \\
\hline
\end{tabular}

Panel B: With number of employee controls

\begin{tabular}{lccc}
\hline & $\log ($ Revenue $)$ & $\log (\mathrm{AUM})$ & $\log ($ Accounts $)$ \\
\hline Protocol & 0.109 & $0.304^{* * *}$ & $0.438^{* * *}$ \\
$\log ($ employees $)$ & {$[1.07]$} & {$[3.43]$} & {$[4.13]$} \\
& $1.002^{* * *}$ & $0.374^{* * *}$ & $0.412^{* * *}$ \\
Firm FE & {$[28.22]$} & {$[6.83]$} & {$[6.60]$} \\
Year FE & $\mathrm{Y}$ & $\mathrm{Y}$ & $\mathrm{Y}$ \\
Observations & $\mathrm{Y}$ & $\mathrm{Y}$ & $\mathrm{Y}$ \\
R-squared & 32,472 & 6,815 & 6,816 \\
\hline
\end{tabular}

